\title{
The treatment of chronic hepatitis B: Focus on adefovir-like antivirals
}

\section{Hans Ludger Tillmann}

Medizinische Klinik und Poliklinik II, Universität Leipzig, Germany
Correspondence: Hans LTillmann

Duke Clinical Research Institute, 2400

Pratt St, Durham, NC 27705, USA

$\mathrm{Tel}+\mathrm{I} 9196684620$

Fax + I 9196687164

Email Hans.Tillmann@duke.edu

\begin{abstract}
Several options for the treatment of hepatitis B have been licensed in the last years: interferon, pegylated interferon, lamivudine, adefovir, entecavir, and telbivudine. In addition tenofovir has been licensed in the EU and is expected to be licensed in the USA in 2008. The antivirals can be divided into "lamivudine-like" and "adefovir-like", which clinically differ in their capacity to induce "YMDD" mutants, which are the hallmark of lamivudine resistance. The differing resistance profile makes them good combination partners, even in the absence of synergy in antiviral potency.
\end{abstract}

Keywords: adefovir, tenofovir, pradefovir, almefovir, antiviral therapy, hepatitis B

\section{Introduction}

Hepatitis B virus (HBV) infection affects about 2 billion people, of whom about 350 million display chronic hepatitis $\mathrm{B}$, defined by presence of hepatitis B surface antigen (HBsAg) in the serum (Lavanchy 2004). It is estimated that between 235,000 and 328,000 people die annually due to liver cirrhosis and hepatocellular carcinoma, respectively (Perz et al 2006).

Transaminases have for the longest time been the hallmark of liver disease, and patients with normal liver transaminases have been considered to have no significant liver disease. Accordingly, guidelines used to state indication for antiviral therapy only in the presence of elevated liver enzymes (de Franchis et al 2003; Liaw et al 2005; Lok and McMahon 2007). This has, however, been challenged, based on recent findings that high viral load seems more important than elevation of liver transaminases (Chen et al 2006; Iloeje et al 2006).

Furthermore, using an antiviral to reduce HBV viral load has been shown to ameliorate liver disease (Liaw et al 2004), so that it is now recommended to start antiviral therapy, despite normal liver enzymes, when there are other sign of liver disease, such as advanced fibrosis or risk factors to develop hepatocellular carcinoma (Cornberg et al 2007).

There are two different ways to inhibit HBV replication, either by using immune modulators such as interferon, pegylated interferon (Marcellin et al 2004; Lau et al 2005) or thymosin alfa (You et al 2006), or with antivirals. Antivirals available at present can then be divided into the "lamivudine-like" (L-nucleosides) and the "adefovir-like" drugs. The "lamivudinelike" and "adefovir-like" drugs differ in their pattern of resistance mutations.

While the "lamivudine-like" antivirals (telbivudine, clevudine, emtricitabin, and even entecavir, though additional mutations are required for full resistance in the latter) share a mutations pattern at position M204 of the YMDD (Tyrosine-MethionineAspartate-Aspartate motif in the catalytic domain of the viral polymerase/reverse transcriptase) motif of the HBV-polymerase, the "adefovir-like" antivirals seem to remain fully active against those mutants (Yang et al 2005).

The currently licensed and soon to be licensed therapies show differences in achieving viral load below a detectability threshold of 300 to 1000 copies per 
$\mathrm{ml}$, as indicated in Figure 1. Additionally, they differ in their selection for viral resistance, which has not yet been reported for interferon, but for all antivirals to different degree.

Nonresponse to interferon might be more based on the cellular than on the viral level, as has been demonstrated in case of HCV infection (Aus dem Siepen et al 2007). In contrast to interferon, resistance to antivirals can occur frequently, especially in case of insufficient response (Han et al 2007). Resistance after one year ranges from below $1 \%$ in adefovir (Hadziyannis et al 2003; Marcellin et al 2003) and entecavir (Chang et al 2006; Lai et al 2006a) to about $32 \%$ in lamivudine-treated patients (Dienstag et al 1999). Long term data on resistance are scarce. There are no real controlled data for lamivudine, but it is generally presumed to rise to about $70 \%$ over 5 years. Likewise, it has been shown that resistance to adefovir emerges with a constant increase from $0 \%, 3 \%, 9 \%$, and $18 \%$ to $29 \%$ within 1,2 , 3,4 , and 5 years, respectively, in HBeAg-negative patients years (Hadziyannis et al 2006). In addition, one must be aware that the chance of developing resistance is higher in HBeAg-positive vs. HBeAg-negative patients (Table 1) (Han et al 2007). For telbivudine reliable 1 and 2 year data are available, while data for entecavir only included subgroups of their patients (Colonno et al 2006), thus making final conclusions difficult. The risk for entecavir resistance is significantly increased with underlying lamivudine resistance (Colonno et al 2006).

\section{Adefovir}

When adefovir was initially developed for HIV therapy, its development was halted due to nephrotoxicity at the doses of 60 and $120 \mathrm{mg}$, which would have been required for HIV therapy (Kahn et al 1999). Because of its anti-HBV-activity, adefovir was still further evaluated for treatment of HBV, where a $10 \mathrm{mg}$ dose was shown to be sufficient to suppress HBV to similar levels as lamivudine, while in that dose there was no significant nephrotoxicity or other toxicity (Izzedine et al 2004).

A clear strength of the adefovir-like nucleosides is their higher genetic barrier to resistance. Though there are no "head to head" studies, adefovir in the licensed $10 \mathrm{mg}$ dose is at least not more efficient than lamivudine, given in $100 \mathrm{mg}$. Still the resistance rate is much lower for adefovir, with "zero" after one year (Hadziyannis et al 2003; Marcellin et al 2003). However, it has been noted that resistance to adefovir develops more frequently in the presence of underlying lamivudine resistance, if lamivudine is not continued (van der Poorten et al 2007).

Furthermore, it has been demonstrated that the $30 \mathrm{mg}$ dose of adefovir would be superior than the $10 \mathrm{mg}$ concerning antiviral efficacy (Marcellin et al 2003), which was recently reinforced by a study using $20 \mathrm{mg}$ daily in 5 lamivudine-resistant patients with insufficient response to the $10 \mathrm{mg}$ adefovir dose (Hezode et al 2007). Thus, a higher dose of adefovir would be desired, but the $30 \mathrm{mg}$ dose was shown to lead to a significantly more frequent

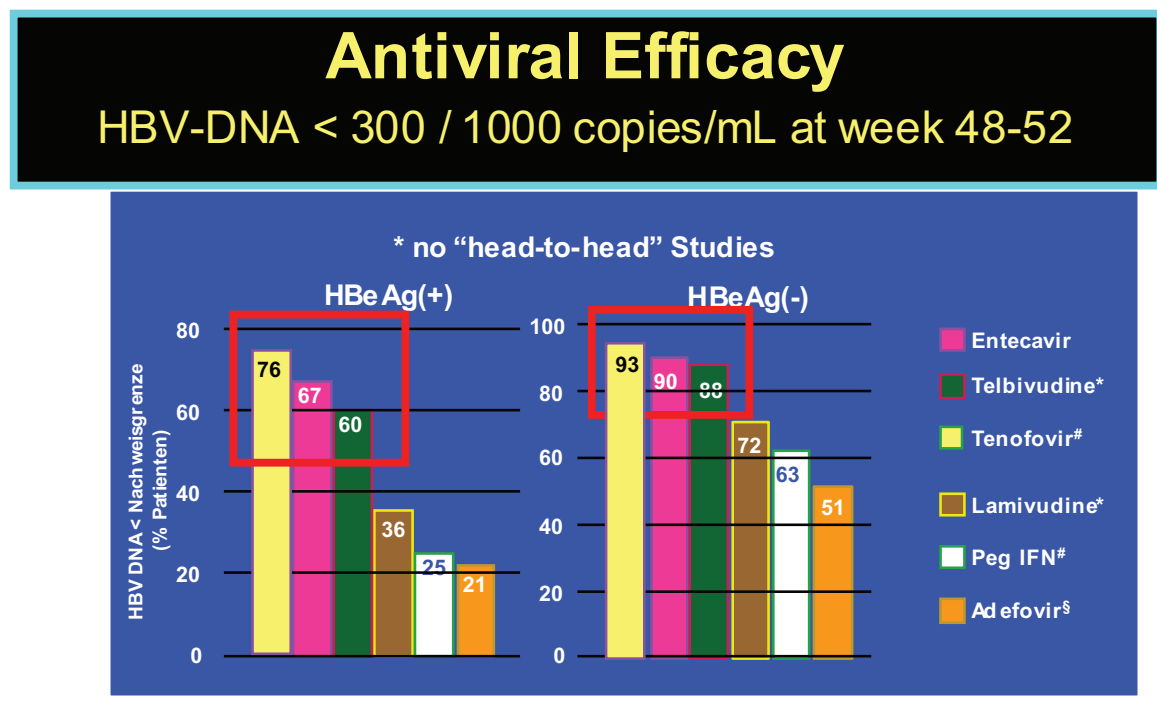

Figure I Efficacy of HBV drugs (48-52 week data). Lai CL, et al. Hepatology 2005; 42:748A (AASLD abstract LB0I); Lau G, et al. NEJM 2005; 352:2882-2695; Chang T-T, et al. NEJM 2006; 354:1000-1010; Marcellin P, et al. NEJM 2003;348:808-816. "Heathcote J et al.AASLD 2007, Marcellin P, et al. AASLD 2007.

Notes: "Undetectable $<300$ copies $/ \mathrm{mL}$, \#Undetectable $<400$ copies $/ \mathrm{mL}$, ${ }^{\S}$ Undetectable $<1000$ copies $/ \mathrm{mL}$. 
Table I Resistance defined by I log viral load increase over nadir after one and two years within the GLOBE trial

\begin{tabular}{llllll}
\hline Rate of resistance & \multicolumn{2}{l}{ Lamivudine } & & \multicolumn{2}{l}{ Telbivudine } \\
\cline { 2 - 3 } & HBeAg-positive & HBeAg-negative & & HBeAg-positive & HBeAg-negative \\
\hline Year I & 8.2 & 3.0 & 8.5 & 2.1 \\
Year 2 & 35.0 & 21,6 & 21.6 & 8.6 \\
\hline
\end{tabular}

Adapted from Han et al (2007).

increase in creatinine levels than the $10 \mathrm{mg}$ dose (Marcellin et al 2003).

The viral load reduction achieved by lamivudine is no longer the standard, but instead the viral load reduction achieved by entecevair and telbivudine is preferred, both leading to more than 6 log viral load reduction (Chang et al 2006; Han et al 2007). As a result, it would be more beneficial to utilise adefovir-like drugs, with both higher antiviral activity and lower toxicities. Adefovir-like drugs are currently pradefovir (also known as remofovir; almefovir; Hepavir $\mathrm{B}^{\mathrm{TM}}$ ) (Tillmann 2007), which is a prodrug of adefovir, tenofovir, LB-80380 (also known as ANA 380) and alamifovir (also known as MCC-478) (Chan et al 2005).

\section{Pradefovir, a liver-targeted adefovir}

Based on the concept of increased levels of adefovir at the main target organ, the liver, with low systemic exposure, pradefovir was developed. Pradefovir (also known as remofovir; almefovir; Hepavir B) is based on adefovir and a specific side chain making it into an inert drug, until activation through cytochrome p450 (CYP3A4). As this compound is abundant in the liver but scarce elsewhere in the body (Berggren et al 2007), it is almost exclusively activated in the liver, thereby high drug levels are achieved in the liver, while the systemic exposure has been shown to be low (Lin et al 2004).

Dependence on CYP3A4, however, makes pradefovir prone to interaction with other drugs that also require, induce or inhibit CYP3A4. In line with the need for further metabolization, the AUC variation was higher on pradefovir compared to adefovir (Lee et al 2006). The antiviral activity in that phase II study was more pronounced on pradefovir doses of $10 \mathrm{mg}$ and higher. The open-label phase II trials compared pradefovir $(5,10,20$, or 30 $\mathrm{mg}$ ) with $10 \mathrm{mg}$ adefovir in chronically HBV-infected patients, who were treated for 24 to 48 weeks (Lee et al 2006, Lin et al 2006) This study included 47, 49, 48, 48, and 50 patients into the pradefovir 5, 10, 20 and $30 \mathrm{mg}$ arm and the $10 \mathrm{mg}$ adefovir arm respectively. After 24 and 48 weeks, a viral reduction was described to be 3.39 , $4.22,4.33$, and $5.02 \log$ copies per $\mathrm{ml}$ for the pradefovir mesylate dose of 5, 10, 20, and $30 \mathrm{mg}$, respectively, compared with 3.66 with $10 \mathrm{mg}$ adefovir dipivoxil after 24 weeks (Lee et al 2006) and 4.09, 4.84, 4.89, $5.54 \mathrm{log}$ copies per $\mathrm{ml}$ for the pradefovir mesylate dose of 5,10 , 20 , and $30 \mathrm{mg}$, respectively, compared to $4.19 \mathrm{on} 10 \mathrm{mg}$ adefovir dipivoxil after 48 weeks (Lin et al 2006). However, pradefovir was recently put on hold concerning its further development based on increased tumor incidence in animal studies (Tillmann 2007). At present, it is unclear whether this is a class effect of "adefovir-like" substances, the high doses of adefovir in the liver, or related to the prodrug delivery used here.

\section{Tenofovir}

Tenofovir as adefovir was developed for HIV therapy and has proven to have lower renal toxicity and good activity, actually making it currently one of the top nucleoside reverse transcriptase inhibitor backbones in therapies for HIV (De Clercq 2007). Nonetheless, renal toxicity is still a concern in relation to tenofovir, though not quite proven to be causally associated (Röling et al 2006). It has been demonstrated in some case series that tenofovir, at least in the dose of $245 \mathrm{mg}$ tenofovir dipivoxil equivalent to $300 \mathrm{mg}$ tenofovir dipivoxil fumarate equivalent to $136 \mathrm{mg}$ tenofovir as given for $\mathrm{HIV}$, is superior to the $10 \mathrm{mg}$ dose of adefovir (van Bömmel et al 2004), which has been reinforced by reactivation after switching from tenofovir to adefovir (van Bömmel and Berg 2005; Del Poggio et al 2007) and improved suppression after switching from adefovir to tenofovir (van Bömmel et al 2006). A trend towards better response has also been seen in a placebo controlled trial of HIV infected patients (Peters et al 2006).

There are two controlled trials currently underway comparing tenofovir to adefovir, which have only been presented as press releases (Gilead 2007a, 2007b) and abstract form. The one year data have been presented at the 2007 AASLD (American Association for the Study of the Liver) annual meeting. According to these press releases and the presentations (Heathcote et al 2007; Marcellin et al 2007), Tenofovir is significantly more potent than adefovir. Tenofovir achieved the highest rates 
Table 2 Viral load reduction on alamifovir

\begin{tabular}{|c|c|c|c|c|c|c|c|c|c|}
\hline \multirow[b]{2}{*}{ Parameter } & \multirow[b]{2}{*}{$N$} & \multirow[b]{2}{*}{ Placebo } & \multirow{2}{*}{$\begin{array}{l}\frac{2.5 \mathrm{mg} / \mathrm{d}}{2.5 \mathrm{mg}} \\
\text { QD }\end{array}$} & \multicolumn{2}{|l|}{$5 \mathrm{mg} / \mathrm{d}$} & \multicolumn{2}{|c|}{$10 \mathrm{mg} / \mathrm{d}$} & \multicolumn{2}{|c|}{$20 \mathrm{mg} / \mathrm{d}$} \\
\hline & & & & $\begin{array}{l}2.5 \mathrm{mg} \\
\text { BID }\end{array}$ & $\begin{array}{l}5 \mathrm{mg} \\
Q D\end{array}$ & $\begin{array}{l}5 \mathrm{mg} \\
\text { BID }\end{array}$ & $\begin{array}{l}10 \mathrm{mg} \\
\text { QD }\end{array}$ & $\begin{array}{l}10 \mathrm{mg} \\
\text { BID }\end{array}$ & $\begin{array}{l}20 \mathrm{mg} \\
\text { QD }\end{array}$ \\
\hline Log-change on day 29 & Mean drop & 0,064 & 1,52 & 2,02 & 1,96 & 1,98 & 2,49 & 2,53 & 2,50 \\
\hline
\end{tabular}

in undetectability of HBV-DNA observed in any drug trial related to hepatitis B. However, the comparison to the other currently marketed drug is difficult given that the viral load of the enrolled patients was in average about 1 $\log$ lower than in the other trials. It might well be that the antiviral efficacy is superior to that of the other currently marketed drugs. However, to finally asses this, a head to head study would be required, but unlikely to take place. However, in addition to its efficacy, no emergence of viral breakthrough has been observed on tenofovir. In addition, HBsAg loss, otherwise mostly only seen in relation to interferon-based therapies has been observed in about $3 \%$ after 48 weeks and $4 \%$ of tenofovir-treated patients after 69 weeks of therapy (Heathcote et al 2008). However, no loss of HBsAg has been observed in HBeAg-negative patients on tenofovir.

After tenofovir's licensure for HBV therapy, it is probable that adefovir's only indication will be the HIV-positive patient needing HBV-treatment, but not yet requiring antiHIV therapy (Thio and Locarnini 2007).

A mutation, rtA194T, has been reported to emerge on tenofovir (Sheldon et al 2005), but it did not lead to a real viral load increase, thus awaiting further confirmation.

\section{Alamifovir}

Alamifovir, also known as MCC-478 or LY582563, is a adenosine nucleotide analogue, which has activity against both HIV and HBV. In a phase I study $66 \mathrm{HBV}-\mathrm{DNA}$ positive patients were randomized to alamifovir or placebo in a 3:1 ratio within each of 7 dosing groups: $2.5 \mathrm{mg}$ BID, $5 \mathrm{mg}$ BID, $10 \mathrm{mg}$ BID, $2.5 \mathrm{mg}$ QD, $5 \mathrm{mg}$ QD, $10 \mathrm{mg}$ QD, and $20 \mathrm{mg}$ QD. That study showed no difference between once daily and twice daily dosing (Table 2). In this small study, there were also no significant differences between the groups except towards placebo. At present, no new data have been presented within the last two years.

\section{LB-80380}

LB-80380 is also known as ANA 380, and is a 9-[1-(Ph osphonomethoxycyclopropyl) methyl] guanine (PMCG). Even though it is frequently regarded as a "adefovir-like" nucleotide, it is considered, at least by some, as a representative of a novel class of phosphonate nucleosides that blocks HBV replication with an excellent potency $\left(\mathrm{EC}_{50}\right.$ of $0.5 \mu \mathrm{M}$ ) in HepG2 2.2.15 cells (Choi et al 2004). LB-80380 did not show any cytotoxicity in several human cell lines in concentrations up to 2000 times of that required for an EC50 for HBV inhibition. It seems not to inhibit HIV replication, at least at $30 \mu \mathrm{M}$, which is 60 times the dose required for HBV. This, however, requires further evaluation in light of the unexpected activity of entecavir against HIV (McMahon et al 2007). Furthermore, in its oral form, PMCDG dipivoxil, excellent efficacy was achieved in $\mathrm{HBV}$ infected woodchucks at $5 \mathrm{mg} / \mathrm{kg} / \mathrm{d}$ (Choi et al 2004).

In vivo LB-80380 has been also tested in naïve and lamivudine refractory patients (Yuen et al 2006). When doses of $30,60,120$, and $240 \mathrm{mg}$ were given once daily for 4 weeks, a mean maximum viral load reduction of 3.05, 4.20, 3.67, and $3.68 \log 10$ copies/ml was achieved for the $30,60,120$, and $240 \mathrm{mg}$ doses, respectively, in naïve patients (Yuen et al 2006). Slightly lower reduction was achieved in lamivudine refractory patients with $2.1,2.5,2.6,3.0$, and $3.0 \log 10$ as well as $2.8,3.2,3.9$, and $3.7 \log 10$ after 4 and 12 weeks, respectively in the $30,60,90,150$, and $240 \mathrm{mg}$ dose groups (Lai et al 2006b).

\section{Conclusions}

In summary, the "adefovir-like" drugs best used in practice are adefovir in the HIV-infected patient in need of anti-HBV therapy, while not yet needing anti-HIV therapy (Thio and Locarnini 2007). In all other patients, I would presume tenofovir to take over, where adefovir is currently used given its lower toxicity and higher activity. Whether any of the other "adefovir-like" drugs will make it to the market remains to be seen. It is probable that all could be well combined with lamivudine, which will soon be off-patent. Thus, it might be a cheap but potentially very active addition to any "adefovir-like" drug, given their different resistance profile. However, in the case of tenofovir, this is not required, given its existence in combination with the lamivudine-like drug emtricitabine. 


\section{Disclosure}

The author reports no conflicts of interest.

\section{References}

Aus dem Siepen M, Oniangue-Ndza C, Wiese M, et al. 2007. Interferonalpha and ribavirin resistance of Huh7 cells transfected with HCV subgenomic replicon. Virus Res, 125:109-13.

Berggren S, Gall C, Wollnitz N, et al. 2007. Gene and protein expression of P-glycoprotein, MRP1, MRP2, and CYP3A4 in the small and large human intestine. Mol Pharm, 4:252-7.

Chan C, Abu-Raddad E, Golor G, et al. 2005. Clinical pharmacokinetics of alamifovir and its metabolites. Antimicrob Agents Chemother, 49:1813-22.

Chang TT, Gish RG, de Man R, et al. 2006. A comparison of entecavir and lamivudine for HBeAg-positive chronic hepatitis B. $N$ Engl $J$ Med, 354:1001-10.

Chen CJ, Yang HI, Su J, et al. 2006. REVEAL-HBV Study Group. Risk of hepatocellular carcinoma across a biological gradient of serum hepatitis B virus DNA level. JAMA, 295:65-73.

Choi JR, Cho DG, Roh KY, et al. 2004. A novel class of phosphonate nucleosides. 9-[(1-phosphonomethoxycyclopropyl)methyl]guanine as a potent and selective anti-HBV agent. J Med Chem, 47:2864-9.

Colonno RJ, Rose RE, Pokornowski K, et al. 2006. Assessment at three years shows high barrier to resistance is maintained in entecavir-treated nucleoside naïve patients while resistance emergence increases over time in lamivudine refractory patients. Hepatology, 44:229-30.

Cornberg M, Protzer U, Dollinger MM, et al. 2007. Prophylaxis, diagnosis and therapy of hepatitis-B-virus-(HBV) infection: upgrade of the guideline. AWMF-Register 021/011. Z Gastroenterol, 45:1287-328.

De Clercq E. 2007. Anti-HIV drugs. Verh K Acad Geneeskd Belg, 69:81-104.

de Franchis R, Hadengue A, Lan G, et al; EASL Jury. 2003. EASL International Consensus Conference on Hepatitis B. 13-14 September, 2002. Geneva, Switzerland. Consensus statement. J Hepatol, 39:3-25.

Del Poggio P, Zaccanelli M, Oggionni M, et al. 2007. Low-dose tenofovir is more potent than adefovir and is effective in controlling HBV viremia in chronic HBeAg-negative hepatitis B. World J Gastroenterol, 13:4096-9.

Dienstag JL, Schiff ER, Wright TL, et al. 1999. Lamivudine as initial treatment for chronic hepatitis B in the United States. $N$ Engl J Med, 341:1256-63.

Gilead. 2007a. Phase III Study evaluating Gilead's Viread ${ }^{\circledR}$ for the treatment of chronic hepatitis B virus meets primary endpoint [online]. Accessed on May 28, 2008. URL:http://www.gilead.com/wt/sec/ pr_1012569.

Gilead. 2007b. Second Phase III Study evaluating Gilead's Viread ${ }^{\circledR}$ for the treatment of chronic hepatitis B virus meets primary endpoint [online]. Accessed on May 28, 2008. URL:http://www.gilead.com/ wt/sec/pr_1018988.

Hadziyannis SJ, Tassopoulos NC, Heathcote EJ, et al. 2003. Adefovir dipivoxil for the treatment of hepatitis $\mathrm{B}$ e antigen-negative chronic hepatitis B. N Engl J Med, 348:800-7.

Hadziyannis SJ, Tassopoulos NC, Heathcote EJ, et al. 2005. Long-term therapy with adefovir dipivoxil for $\mathrm{HBe} A g$-negative chronic hepatitis B. N Engl J Med, 352:2673-81.

Hadziyannis SJ, Tassopoulos NC, Heathcote EJ, et al. 2006. Long-term therapy with adefovir dipivoxil for $\mathrm{HBeAg-negative} \mathrm{chronic} \mathrm{hepatitis} \mathrm{B}$ for up to 5 years. Gastroenterology, 131:1743-51.

Han S, Lai C, Gane EJ, et al. 2007. Telbivudine globe trial at year two: efficacy, safety, and predictors of outcome in patients with chronic hepatitis B. Gastroenterology, 132:765.

Heathcote EJ, Gane E, De Man R, et al. A Randomized, Double-Blind, Comparison of Tenofovir DF (TDF) Versus Adefovir Dipivoxil (ADV) for the Treatment of HBeAg Positive Chronic Hepatitis B (CHB): Study GS-US-174-0103. Hepatology 2007: (Suppl.1) 231A.
Heathcote EJ, George J, Gordon S, et al. Tenofovir Disoproxil Fumarate (TDF) for the treatment of HBeAg-positive chronic hepatitis B: Week 72 TDF data and week 24 Adefvoir Dipivoxil switch data (Study 103). J Hepatol 2008: (Suppl.2) S32.

Hezode C, Chevaliez S, Bouvier-Alias M, et al. 2007. Efficacy and safety of adefovir dipivoxil $20 \mathrm{mg}$ daily in HBeAg-positive patients with lamivudine-resistant hepatitis B virus and a suboptimal virological response to adefovir dipivoxil $10 \mathrm{mg}$ daily. J Hepatol, 46:791-6.

Iloeje UH, Yang HI, Su J, et al; Risk Evaluation of Viral Load Elevation and Associated Liver Disease/Cancer-In HBV (the REVEAL-HBV) Study Group. 2006. Predicting cirrhosis risk based on the level of circulating hepatitis B viral load. Gastroenterology, 130:678-86.

Izzedine H, Hulot JS, Launay-Vacher V, et al. 2004. Renal safety of adefovir dipivoxil in patients with chronic hepatitis B: two double-blind, randomized, placebo-controlled studies. Kidney Int, 66:1153-8.

Jacquard AC, Brunelle MN, Pichoud C, et al. 2006. In vitro characterization of the anti-hepatitis B virus activity and cross-resistance profile of 2',3'-dideoxy-3'-fluoroguanosine. Antimicrob Agents Chemother, 50:955-61.

Kahn J, Lagakos S, Wulfsohn M, et al. 1999. Efficacy and safety of adefovir dipivoxil with antiretroviral therapy: a randomized controlled trial. JAMA, 24:2305-12.

Lai CL, Shouval D, Lok AS, et al. 2006a. Entecavir versus lamivudine for patients with $\mathrm{HBeAg}$-negative chronic hepatitis B. N Engl J Med, 354:1011-20.

Lai CL, Han KH, Yoon SK, et al. 2006b. Phase II, multi-centre, doseescalating study of LB8030 (ANA380) in hepatitis B patients with lamivudine resistant YMDD mutant HBV. J Hepatol, 44:5.

Lau GK, Piratvisuth T, Luo KX, et al. 2005. Peginterferon Alfa-2a, lamivudine, and the combination for $\mathrm{HBeAg}$-positive chronic hepatitis B. N Engl J Med, 352:2682-95.

Lavanchy D. 2004. Hepatitis B virus epidemiology, disease burden, treatment, and current and emerging prevention and control measures. $J$ Viral Hepat, 11:97-107.

Lee KS, Lim SG, Chuang WL, et al. 2006. Safety, tolerability and antiviral activity of pradefovir mesylate in patients with chronic hepatitis $B$ virus infection: 48-week analysis of a phase 2 study. J Hepatol, 44:274.

Liaw YF, Leung N, Guan R, et al; Asian-Pacific Consensus Update Working Party on Chronic Hepatitis B. 2005. Asian-Pacific consensus statement on the management of chronic hepatitis B: a 2005 update. Liver Int, 25:472-89.

Liaw YF, Sung JJ, Chow WC, et al; Cirrhosis Asian Lamivudine Multicentre Study Group. 2004. Lamivudine for patients with chronic hepatitis B and advanced liver disease. $N$ Engl J Med, 351:1521-31.

Lin C, Xu C, Yeh LT, et al. 2006. Pharmacokinetics and pharmacodynamics of pradefovir mesylate, a liver-targeting pro-drug of PMEA, in HBV patients. J Hepatol, 44:16.

Lin CC, Yeh LT, Vitarella D, et al. 2004. Remofovir mesylate: A prodrug of PMEA with improved liver-targeting and safety in rats and monkeys. Antivir Chem Chemother, 15:307-17.

Lok AS, McMahon BJ. 2007. Chronic hepatitis B. Hepatology, 45:507-39.

Marcellin P, Chang TT, Lim SG, et al. 2003. Adefovir dipivoxil for the treatment of hepatitis B e antigen-positive chronic hepatitis B. N Engl $J$ Med, 348:808-16.

Marcellin P, Lau GK, Bonino F, et al. 2004. Peginterferon alfa-2a alone, lamivudine alone, and the two in combination in patients with $\mathrm{HBeAg}-$ negative chronic hepatitis B. N Engl J Med, 351:1206-17.

Marcellin P, Buti M, Krastev Z, et al. A Randomized, Double-Blind, Comparison of Tenofovir DF (TDF) versus Adefovir Dipivoxil (ADV) for the Treatment of HBeAg-Negative Chronic Hepatitis B (CHB): Study GS-US-174-0102 Hepatology 2007: (Suppl.1) 231A.

Marcellin P, Jacobson I, Habersetzer F, et al. Tenofovir Disoproxil Fumarate (TDF) for the treatment of HBeAg-negative chronic hepatitis B: Week 72 TDF data and week 24 Adefvoir Dipivoxil switch data (Study 102). J Hepatol 2008: (Suppl.2) S26.

McMahon MA, Jilek BL, Brennan TP, et al. 2007. The HBV drug entecavir - effects on HIV-1 replication and resistance. $N$ Engl J Med, 356:2614-21. 
Perz JF, Armstrong GL, Farrington LA, et al. 2006. The contributions of hepatitis $\mathrm{B}$ virus and hepatitis $\mathrm{C}$ virus infections to cirrhosis and primary liver cancer worldwide. J Hepatol, 45:529-38.

Peters MG, Andersen J, Lynch P, et al. 2006. Randomized controlled study of tenofovir and adefovir in chronic hepatitis B virus and HIV infection: ACTG A5127. Hepatology, 44:1110-6.

Röling J, Schmid H, Fischereder M, et al. 2006. HIV-associated renal diseases and highly active antiretroviral therapy-induced nephropathy. Clin Infect Dis, 42:1488-95.

Sheldon J, Camino N, Rodes B, et al. 2005. Selection of hepatitis B virus polymerase mutations in HIV-coinfected patients treated with tenofovir. Antivir Ther, 10:727-34.

Soon DK, Lowe SL, Teng CH, et al. 2004. Safety and efficacy of alamifovir in patients with chronic hepatitis B virus infection. J Hepatol, 41:852-8.

Thio CL, Locarnini S. 2007. Treatment of HIV/HBV coinfection: clinical and virologic issues. AIDS Rev, 9:40-53.

Tillmann HL. 2007. Drug evaluation: Pradefovir, a liver-targeted prodrug of adefovir against HBV infection. Curr Opin Investig Drugs, 8:682-90

van Bommel F, Berg T. 2005. Reactivation of viral replication after replacement of tenofovir by adefovir. Hepatology, 42:239-40. van Bommel F, Wunsche T, Mauss S, et al. 2004. Comparison of adefovir and tenofovir in the treatment of lamivudine-resistant hepatitis B virus infection. Hepatology, 40:1421-5.

van Bommel F, Zollner B, Sarrazin C, et al. 2006. Tenofovir for patients with lamivudine-resistant hepatitis B virus (HBV) infection and high $\mathrm{HBV}$ DNA level during adefovir therapy. Hepatology, 44:318-25.

van der Poorten D, Prakoso E, Khoo TL, et al. 2007. Combination adefovirlamivudine prevents emergence of adefovir resistance in lamivudineresistant hepatitis B. J Gastroenterol Hepatol, 22:1500-5.

Yang H, Qi X, Sabogal A, Miller M, Xiong S, Delaney WE 4th. 2005. Crossresistance testing of next-generation nucleoside and nucleotide analogues against lamivudine-resistant HBV. Antivir Ther, 10:625-33.

You J, Zhuang L, Cheng HY, et al. 2006. Efficacy of thymosin alpha-1 and interferon alpha in treatment of chronic viral hepatitis B: a randomized controlled study. World J Gastroenterol, 12:6715-21.

Yuen MF, Kim J, Kim CR, et al. 2006. A randomized placebo-controlled, dose-finding study of oral LB80380 in HBeAg-positive patients with chronic hepatitis B. Antivir Ther, 11:977-83. 